\section{REFUGE \\ c/o Refugee Documentation Project, \\ York University, 4700 Keele Street, \\ Downsview, Ontario M3J 2R6 \\ Editor: \\ Howard Adelman \\ Managing Editor: \\ Caroline Stephens \\ Editorial Assistant: \\ Shirra Freeman \\ Technical Assistant: \\ Patricia Sandquist \\ Editorial Board: \\ Douglas Cohen, Montreal \\ Claudio Duran, Toronto \\ Arie van Eek, Burlington \\ Donald Ferguson, Toronto \\ Michael Pitman, Toronto \\ Linda Weigl, Regina \\ Typesetting and Layout: \\ Publications Department, \\ York University \\ Refuge is dedicated to encouraging assistance to refugees, by providing a forum for sharing infor- mation and opinion on Canadian and interna- tional issues pertaining to refugees. It is published five times a year in October, December, February, dependent periodical supported by a grant from the Canada Employment and Immigration Com- mission; by private donations; and by subscrip- tions. It is a forum for discussion, and the views expressed do not necessarily reflect those of its funders, staff or Editorial Board. \\ All material in Refuge may be reproduced without permission unless copyrighted or other- wise indicated. Credit should be given to the author or source if named. \\ Logo design: \\ Dreadnaught Cooperative Inc., Toronto \\ Second Class Mail Registration No. 5512 ISSNO229-5113}

\section{Letters}

\section{To the Editor:}

While my wife and I were on a recent visit to the USSR, we visited with several refusenik families. These people were all members of the Jewish religion and were being helped, in some form or other, by synagogues and/or other Jewish organizations in the free world. However, at the home of one of these families, we met another family: the Churins. Igor Churin and his wife Ann and their two children are not Jewish, belonging to no religious group of any kind. Because virtually all of the help

\title{
Canadian Foundation for Refugees Plans Refugee Newsletter
}

August 3, 1983

Dear Dr. Adelman:

Please find enclosed an outline for a prototype NEWSLETTER that the Canadian Foundation for Refugees will produce for distribution across Canada. The Foundation invites both community agencies and individuals concerned about the cause of refugees to assist in this undertaking. It is the intention to publish the newsletter on a quarterly basis starting with the first issue in early fall (October).

The newsletter will assist the communication among those people involved in aiding refugees. It will form part of the networking mechanism so that workers can share with each other their experiences, concerns, issues, approaches and/or solutions. This should thereby help overcome feelings of isolation.

Editor's Note: Above is an excerpt from a letter sent to me by the Canadian Foundation for Refugees. Why is the Foundation planning to produce such a newsletter when Refuge is already being published? Further, the proposed contents of the newsletter overlap ours. This is a waste of government funds. One or the other should not be published. We would like to hear the views of our readers.
Dear Howard:

We appreciate the opportunity to comment before publication of your note.

At the outset, we wish to express our total disagreement with your 'Editor's Note'. The type of newsletter we wish to publish is not being published by anyone. Refuge doesn't begin to serve the need we are addressing. Both Refuge and our newsletter should be published, as they serve two very distinct areas of concern and endeavor re refugees.

The statements you make are very biased. You are however entitled to your own opinion.

The letter you received was sent to some 200 persons and organizations working with or on behalf of refugees. We have presently received 25 responses; 23 are positive, enthusiastic and extremely supportive of this effort, one is witholding their (sic) opinion, and one (yours) opposed.

Earlier, we mentioned that there are two areas of concern and endeavor re refugees. These are advocacy and assistance. These two areas are not in competition; they are complementary. By the same token, there will always be some areas of overlap between the two as it is impossible to always keep them as unique and mutually exclusive areas

(Continued on p. 11) for refuseniks comes from religious organizations, Christian and Jewish, the Churin family has been the recipient of none. We were struck by this apparent inequity and so are seeking the assistance of some non-sectarian group that would undertake to assist the Churins.

Igor Churin, an engineer specialist in structural and mechanical vibrations, applied for his exit visa about 5 years ago. It was denied and he was immediately demoted to the position and salary of a beginner and stripped of his doctoral standing, continuing to work in the same plant in his reduced status. He is a most remarkable man, fluent in English, German, and of course Rus- sian. He learned English completely on his own, by listening to Voice of America boadcasts. He appears to be an extremely intelligent, high-principled man who wished to emigrate because, as he says, he seeks a better life for his children (Tanja about 11 and Alexander about 7). They are good people who would be a credit to any society in which they chose to live.

Is there any help that anyone can offer these fine people?

Paul H. Klein Willowdale, Ontario Their address: Igor Churin Profsojuznaja 75-3-95 117342 Moscow, USSR (Letters continued on p. 11) 
Letters

(cont'd from p. 2)

\section{To the Editor:}

I want to let you know how interesting, informative and useful your Refuge publication is and has been in the past.

Perhaps you can hep me, too. We are interested in a documentation project regarding minor unaccompanied refugees, necessitating travel and related costs. Any financial assistance from interested people and groups would be welcome. Our estimated cost is $\$ 3,300$ (U.S. funds). The money would enable representatives from our organization to visit camps in Southeast Asia. The purpose of the visit would be to establish direct contacts in the camps and to search for unaccompanied minors who could be sponsored to come to Canada.

In addition, we want to liaise with interested people or groups in Ontario or elsewhere in Canada who are concerned with these "minors" especially in Central America, Indochina and Hong Kong.

Lloyd Jones

Centre for International Co-operation

Thunder Bay, Ontario

The Honourable Monique Bégin Minister of Health and Welfare Ottawa

Dear Mme Bégin:

What is going to happen to refugee doctors who fail to obtain internships in Canadian hospitals?

Are we as a nation going to stand by and let some man-made rules or bureaucratic red tape cause us to throw away (waste) these human resources and deprive many of our people of better medical services? What is being done to solve this problem, and solve it quickly? Some of these people don't have too much time left in their qualifying period.

\section{Sincerely yours, E.A. Chenard Executive Director Canadian Foundation for Refugees}

Editor's Note: If you wish to see a full text of this letter, please write to the Canadian Foundation for Refugees.

\section{Canadian Foundation}

(cont'd from p. 2)

of interest and endeavor. You will always find people and organizations who are primarily interested in one but still having (sic) some interest in the other. Those people and organizations who try to be involved equally in both seem not to be able to do a good job in either area, or one succeeds at the expense of the other.

The advocacy role involves making noise, publishing information, and initiating other activities which focus attention upon, and create interest in refugee problems. The assistance role however, concerns itself with the problems of emergency aid, repatriation, integration and resettlement.

The advocacy role is necessary to create and improve a favourable political climate in Canada for refugees. Your interest has shifted primarily to advocacy work with Refuge functioning as an advocacy publication. Similarly, you feel that the Foundation should adopt an advocacy role and get involved with crisis research and other related activities. The Foundation has, however, chosen to concern itself with providing assistance to those working at resettling refugees in Canada.

The Foundation is, however, also interested in public education, in creating among Canadians a climate favourable to the plight of refugees globally and the acceptance of refugees in Canada. It is in this area where there is the greatest potential for overlap between Refuge and the proposed newsletter. However, there is not much need for concern since the readers of both publications are or will be the initiated or converted.

As an advocacy forum, Refuge is a necessary publication. Everyone we speak to who has read Refuge agrees that it is good and should get better. It, however, does not fulfil the basic needs of those involved and working in the resettlement of refugees in Canada.

These organizations need a forum in which they can get to know each other, know who their counterparts are in the next community, in all the communities across Canada. They need to be able to communicate in the parlance of the daily practitioner, not in some academic or intellectual forum or symposium. The Foundation expects to provide that forum in this proposed newsletter. It will be their newsletter, not the Foundation's; a forum primarily for exchanging and sharing, not debating.

There is a need for both Refuge and the type of newsletter we propose. They will complement each other, not duplicate or compete. We want to see Refuge continue and expand in what it is doing, and we want to see the proposed newsletter develop and grow. There is room for both.

So, Howard, poll your readers. This is your prerogative and we would be the last to deny you this. Furthermore, we would be very interested in the response you obtain; but only if you poll your readers without bias and try not to influence their opinion. Present both viewpoints and let the readers make up their own mind. Is it asking too much to be treated fairly and without prejudice?

We look forward to your response and the results of your poll.

Sincerely yours E.A. Chenard A/Executive Director Canadian Foundation for Refugees

Editor's Note: Since when is providing information advocacy? Is analysis advocacy? Is the digest and publication of research results advocacy? The Foundation has proven itself incapable of acting on the basis of research results, let alone undertaking any research itself. To call engagement in research advocacy only reveals a total lack of understanding of the meaning of research. The writer mocks logic. Dividing concern and effort for refugees into two exhaustive categories advocacy and assistance - is silly.

The response is riddled with other conceptual confusions. To be 'without bias' is not to be 'without thought'. We attempt to minimize bias by publishing different perspectives on controversial issues. According to the writer's definitions our position is biased in commenting on the proposed newsletter whereas the " 23 positive, enthusiastic and extremely supportive" views are unbiased because the Foundation only publishes information and does not advocate anything. 